\title{
Identification and Characterization of Novel Isolates of Pyrenophora tritici-repentis from Arkansas
}

\author{
Shaukat Ali, Suraj Gurung, and Tika B. Adhikari, Department of Plant Pathology, North Dakota State University, \\ NDSU Dept. 7660, P.O. Box 6050, Fargo, ND 58108
}

\begin{abstract}
Ali, S., Gurung, S., and Adhikari, T. B. 2010. Identification and characterization of novel isolates of Pyrenophora tritici-repentis from Arkansas. Plant Dis. 94:229-235.

Tan spot, caused by Pyrenophora tritici-repentis, is an important foliar disease of wheat (Triticum aestivum) worldwide. In a preliminary study, P. tritici-repentis isolates from Arkansas were shown to vary in virulence relative to isolates from other regions of the United States. Therefore, the aim of the current study was to characterize both pathogenic and molecular variations in $P$. tritici-repentis isolates from Arkansas. The virulence of 93 isolates of P. tritici-repentis was evaluated by inoculating five differential wheat cultivars/lines. Based on virulence phenotypes, 63 isolates were classified as race 1, and 30 isolates were assigned to race 3 . A subset of 42 isolates was selected for molecular characterization with the presence or absence of the ToxA and ToxB genes. The results showed that 36 isolates out of 42 tested by polymerase chain reaction (PCR) and Southern analysis lacked the ToxA and ToxB genes. Six isolates harboring the ToxA and ToxB genes induced necrosis and chlorosis on Glenlea and 6B365, respectively. Thirteen ToxA gene-deficient isolates also caused necrosis and chlorosis on Glenlea and 6B365, respectively; however, they did not fit current race classification. In contrast, the remaining 23 ToxA gene-deficient isolates did not cause necrosis, but induced chlorosis on 6B365, showing a disease profile for race 3 . When the virulence of AR LonB2 (an isolate with unclassified race) was compared with known races 1,3 , and 5 of $P$. tritici-repentis on 20 winter wheat cultivars from Arkansas, the virulence phenotypes differed substantially. Taken together, the ToxA and ToxB gene-deficient isolates of $P$. tritici-repentis that induce necrosis and/or chlorosis may produce a novel toxin(s) on wheat.
\end{abstract}

Tan spot, which is caused by Pyrenophora tritici-repentis, is one of the major foliar diseases of wheat (Triticum aestivum L.) worldwide. The disease can reduce yield up to $50 \%$ when highly susceptible wheat cultivars are planted $(23,38,40)$. Due to changes in cultural practices (e.g., minimum or zero tillage), the cultivation of susceptible varieties, and changes in the virulence of the pathogen, tan spot has become a serious concern for wheat producers in the United States (12).

Traditionally, pathogenic races of $P$. tritici-repentis have been characterized based on the ability of isolates to induce necrosis and/or chlorosis on five differential wheat cultivars/lines (4,5,26-28,30,31). Eight races of $P$. tritici-repentis have been identified worldwide (42). At present, races 1 through 5 exist in the United States $(1,5,14,17)$. The ability of $P$. tritici-repentis to induce necrosis and chlorosis on wheat is correlated with the production of hostselective toxins (HSTs). P. tritici-repentis produces three HSTs including Ptr ToxA,

Corresponding author: T. B. Adhikari

E-mail: tika.adhikari@ndsu.edu

Accepted for publication 16 October 2009.

doi:10.1094/PDIS-94-2-0229

(C) 2010 The American Phytopathological Society
Ptr ToxB, and Ptr ToxC $(10,11,13,42)$. Race 1 produces both Ptr ToxA and Ptr ToxC, race 3 produces $P \operatorname{tr}$ ToxC, and race 5 produces Ptr ToxB $(10,11,13,42)$. Among these, both Ptr ToxA and Ptr ToxB are proteineous toxins $(10,11,46)$.

Emerging evidence suggests that Ptr ToxA is internalized into the mesophyll cells and localizes to the chloroplast of sensitive wheat cultivars $(34,36)$. Multiple motifs are required for Ptr ToxA activity on sensitive wheat (32). In addition, Ptr ToxA interacts with a chloroplast protein, ToxA-binding protein 1 (ToxABP1) $(35,39)$. Both Ptr ToxA and Ptr ToxB can inhibit photosystem activity in the chloroplast and may lead to the production of reactive oxygen species (ROS) $(33,43)$. Sensitivity to Ptr ToxA is controlled by a single locus, Tsn1, located on chromosome 5BL in wheat $(6,15)$. The interaction between $T_{s n 1}$ $(6,15)$ and Ptr ToxA (11) follows an inverse gene-for-gene relationship $(31,44)$ and triggers molecular mechanisms similar to those reported previously for avirulence-resistance gene interactions (2).

Arkansas is one of the major winter wheat-producing states in the United States, where tan spot disease is a limiting factor for wheat cultivation (22). Characterization of $P$. tritici-repentis isolates from Arkansas is imperative for developing resistant wheat varieties. When a collection of $P$. tritici-repentis isolates was evaluated on differential wheat cultivars, several necrosis inducing (nec+) isolates of $P$. tritici-repentis were identified $(1,3)$, which lack the ToxA gene (11). The present study was undertaken to gain insight into the pathogenic and molecular variations of the $P$. tritici-repentis isolates from Arkansas. The objectives of this study were to (i) determine the virulence of $P$. triticirepentis isolates on differential wheat cultivars/lines, (ii) analyze isolates for the presence or absence of the ToxA and ToxB genes using PCR and Southern analysis, and (iii) compare the virulence of $\mathrm{AR}$ LonB2 (an isolate of unknown race) with known races 1,3 , and 5 of $P$. triticirepentis on the 20 winter wheat cultivars from Arkansas.

\section{MATERIALS AND METHODS}

Collection and isolation of $P$. triticirepentis isolates. Infected leaf samples from winter wheat varieties were collected from six counties (Arkansas, Craighead, Cross, Jackson, Lonoke, and Prairie) in Arkansas in 2002. Each leaf sample was dissected into 1 - to $2-\mathrm{cm}$ pieces, and 30 leaf segments were placed in plastic petri dishes (9 $\mathrm{cm}$ diameter) containing three layers of moist Whatman no. 1 filter paper. The petri dishes were incubated in an alternating cycle of $24 \mathrm{~h}$ light $\left(22^{\circ} \mathrm{C}\right)$ followed by $24 \mathrm{~h}$ darkness $\left(16^{\circ} \mathrm{C}\right)$ for $96 \mathrm{~h}$ to induce conidiophore production and conidial development, respectively. After incubation, leaf sections were examined using a stereomicroscope, and a single conidium of the fungus was removed with a sterilized steel needle. Single spores were transferred to V8 potato dextrose agar (V8PDA; $150 \mathrm{ml}$ of $\mathrm{V} 8$ juice, $10 \mathrm{~g}$ of Difco PDA, $3 \mathrm{~g}$ of $\mathrm{CaCO}_{3}, 10 \mathrm{~g}$ of agar, and 850 $\mathrm{ml}$ of distilled water) (Difco Laboratories, Detroit, MI) plates and incubated at $21^{\circ} \mathrm{C}$ in darkness for 8 days. In total, 93 singlespore isolates were obtained and stored as described previously (24).

Inoculum preparation. Each isolate of $P$. tritici-repentis was revived by transferring two plugs of the fungal mycelium onto V8-PDA plates. Inoculated plates were wrapped in aluminum foil and maintained at $21^{\circ} \mathrm{C}$ for 5 days in an incubator. Each plate was then flooded with approximately $30 \mathrm{ml}$ of sterile distilled water, and the fungal mycelium was flattened manually with a sterile glass rod. The plates were incubated in an alternating cycle of 18 to $24 \mathrm{~h}$ light at room tempera- 
ture $\left(21\right.$ to $\left.23^{\circ} \mathrm{C}\right)$ followed by 18 to $24 \mathrm{~h}$ of darkness $\left(16^{\circ} \mathrm{C}\right)$. After profuse sporulation, sterilized distilled water $(30 \mathrm{ml})$ was added to each petri dish and inoculum concentration was adjusted to 3,000 conidia/ml prior to inoculation. Two drops of Tween 20 (polyoxyethylene sorbitol ester; SigmaAldrich, Inc., St. Louis, MO) was added to spore suspension $(100 \mathrm{ml})$ as a surfactant.

Virulence analysis. Variations in the virulence of 93 isolates of $P$. tritici-repentis were evaluated on five differential wheat cultivars/lines: Glenlea, 6B365, 6B662, Salamouni, and Katepwa $(26,29,42)$. Wheat cultivar Glenlea harbors $T s n 1$, the gene controlling sensitivity to Ptr ToxA (races 1, 2, 7, and 8); wheat line 6B365 harbors Tscl, the gene controlling sensitivity to Ptr ToxC (races 1, 3, 6, and 8); and wheat line 6B662 harbors Tsc2, the gene controlling sensitivity to Ptr ToxB (races 5, 6, 7, and 8) $(18,30,31,42,44)$. Ptr ToxA induces necrosis on Glenlea, and Ptr ToxB and Ptr ToxC cause chlorosis in wheat lines $6 \mathrm{~B} 362$ and 6B365, respectively (31). For example, symptoms induced by race 1 on wheat cultivar/line Glenlea and 6B365 are presented in Figure 1. Katepwa possesses the genes for sensitivity to Ptr ToxA and Ptr ToxB (races 1, 2, 5, 6, 7, and 8), and these HSTs cause necrosis and/or chlorosis on Katepwa, depending on the production of Ptr ToxA or Ptr ToxB, respectively $(31,42)$. Salamouni is resistant to all known races and insensitive to all three HSTs $(31,42)$.

Three seeds of each cultivar/line were planted in plastic cones $(3.8 \mathrm{~cm}$ in diameter and $20 \mathrm{~cm}$ long) (Stuewe and Sons, Inc., OR) filled with Sunshine Mix \#1 (Fison Horticulture, Vancouver, B.C.). Two-week-old seedlings were inoculated individually with each isolate to runoff using a $\mathrm{CO}_{2}$-pressurized sprayer. Following inoculation, plants were transferred to a mist chamber to provide continuous leaf wetness. After $24 \mathrm{~h}$, seedlings were moved into a growth chamber at $21 / 18^{\circ} \mathrm{C}$ (day/night) with a $16 \mathrm{~h}$ light $/ 8 \mathrm{~h}$ dark photoperiod. The $P$. tritici-repentis race 1 (a reference isolate \# Pti2) was originally collected from a wheat field in South Dakota and was included in this study because it is widely distributed $(1,5,17)$ and produces both Ptr ToxA and Ptr ToxC

$(11,42)$. The virulence of each isolate was assessed 8 days postinoculation (dpi) according to a disease scale of 1 to 5 as proposed previously $(26,27)$, where $1=$ small brown to black spot without tan necrosis and chlorosis; 2 = small dark brown spot with minute amounts of tan necrosis or chlorosis; 3 = small brown to black spot surrounded by a distinct ring of tan necrosis or chlorosis and not coalescing; $4=$ small brown to black spot surrounded by tan necrosis or chlorosis, sometimes coalescing; and $5=$ most lesions consisting of coalescing tan necrotic or chlorotic tissues.

DNA extraction. A subset of 42 isolates was randomly selected and characterized for the presence or absence of the ToxA and ToxB genes (Table 1). Conidia of each isolate were inoculated into $250-\mathrm{ml} \mathrm{Er}$ lenmeyer flasks containing $100 \mathrm{ml}$ of potato dextrose broth. Inoculated flasks were incubated at $22 \pm 2^{\circ} \mathrm{C}$ at $100 \mathrm{rpm}$ for $72 \mathrm{~h}$, and mycelia were then harvested from individual flasks by filtering the inoculum through two layers of Whatman no. 1 filter paper. Mycelia of individual isolates were lyophilized and ground to a fine powder using a high-speed mixer mill (Model MM301; Retsch Inc., Newtown, PA). Genomic DNA was extracted using either DNeasy Plant Mini Kit (Qiagen Inc., Valencia, CA) or a method described previously (17).

Ptr ToxA-based PCR analysis. Primers were chosen to correspond to the coding region of Ptr ToxA. The designed primers amplified a 408-bp region from the middle of the ToxA gene including both intron and exon regions. The primers used were SnToxA Cod1F 5'-CTACAGGAG CGGCAGGAAGC-3' and SnToxA Cod1R 5'-GCTGCATTCTCCAATTTCACG-3' (19). All PCRs were performed at the conditions using an annealing temperature of $60^{\circ} \mathrm{C}$. Each reaction $(10 \mu \mathrm{l})$ consisted of $200 \mathrm{ng}$ of template DNA, $1 \mu \mathrm{l}$ of $10 \times$ buffer, 0.5 units of Taq polymerase (New England BioLabs, Ipswich, MA), 4 pmol of forward and reverse primers, and $0.8 \mu \mathrm{l}$ of $2.5 \mathrm{mM}$ dNTPs. Each PCR was performed on a Dyad Thermal Cycler (Bio-Rad Laboratories, Hercules, CA), and the cycling parameters were 40 cycles of the following: denaturation $60 \mathrm{~s}$ at $94^{\circ} \mathrm{C}$, annealing $60 \mathrm{~s}$

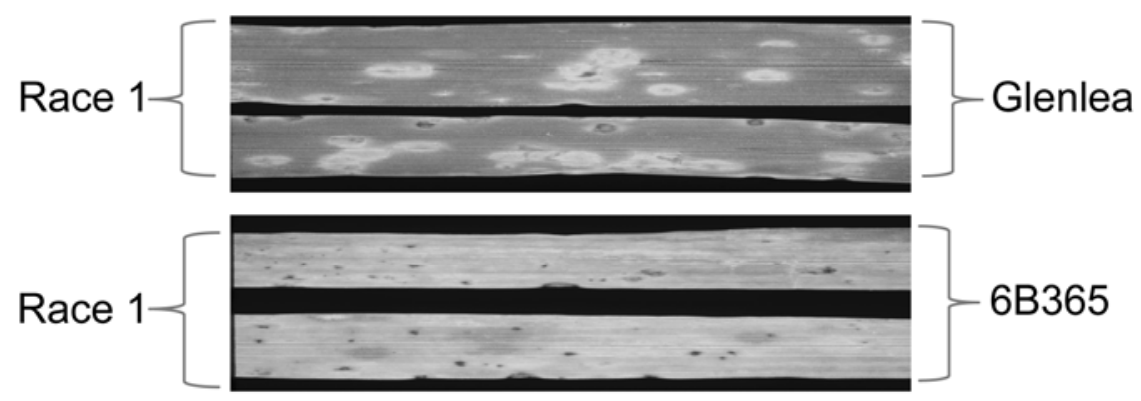

Fig. 1. Symptoms induced by race 1 (isolate \# Pti2) of Pyrenophora tritici-repentis on differential wheat cultivars Glenlea and 6B365. Upper panel shows tan necrosis $\left(\mathrm{Nec}^{+}\right)$and lower panel shows extensive chlorosis $\left(\mathrm{Chl}^{+}\right)$. at $60^{\circ} \mathrm{C}$, and extension $3 \mathrm{~min}$ at $72^{\circ} \mathrm{C}$. The PCR product was visualized on a $1 \%$ agarose gel in $1 \times$ TBE $(10.8 \mathrm{~g}$ of Tris Base, $5.5 \mathrm{~g}$ of boric acid, $5.8 \mathrm{~g}$ of EDTA, and $1,000 \mathrm{ml}$ of deionized water) running buffer.

Southern analysis. The 42 isolates of $P$. tritici-repentis (Table 1) were evaluated for the presence or absence of the ToxA gene (11) using Southern analysis as described previously (16). Primers ToxA-EcoRI 5'GAATTCATGCGTTCTATCCTCGTACTT CT-3' and ToxA-XbaI 5'-TCTAGACTA ATTTTCTAGCTGCATTCTCCA-3', which contain EcoRI and XbaI restriction sites, respectively, were used to amplify and clone the ToxA coding region into a TOPO TA cloning vector as described by the manufacturer (Invitrogen Corp., Carlsbad, CA). Probe labeling, hybridization, and posthybridization washes were done as described previously (16).

Ptr ToxB-based PCR analysis. The 42 selected isolates of $P$. tritici-repentis (Table 1) were analyzed by the ToxB specific primer set (7). Each PCR product $(20 \mu \mathrm{l})$ was separated in $2 \%$ (wt/vol) agarose gels (Sigma-Aldrich, Inc., St. Louis, MO) in $0.5 \times$ TBE buffer (0.089 M Tris-borate, $0.089 \mathrm{M}$ boric acid, and 0.002 M EDTA). Electrophoresis was conducted at $115 \mathrm{~V}$ for $90 \mathrm{~min}$, and gels were stained with ethidium bromide for $15 \mathrm{~min}$ and photographed under UV light.

Comparison of virulence of isolate $A R$ LonB2 with known races 1,3 , and 5 of $P$. tritici-repentis on winter wheat cultivars. Seeds of 20 Arkansas winter wheat cultivars (Table 2) were kindly supplied by Eugene A. Milus, University of Arkansas, Fayetteville and were grown in plastic cones as described above. A representative isolate AR LonB2 from Arkansas, which resembles race 3 and lacks the ToxA gene, was included for comparison with known race 1 (isolate \# Pti2), race 3 (isolate \# Ptr 331-9), and race 5 (isolate \# Ptr DW7) of $P$. tritici-repentis. The isolate Ptr 331-9 was kindly provided by L. Lamari, University of Manitoba, Winnipeg, Canada. Inoculum preparation and inoculation were performed as described above. Two-weekold seedlings of each wheat cultivar were inoculated individually and assessed disease reactions 8 dpi based on a rating scale of 1 to 5 (26).

The experiments were laid out in a randomized complete block design (RCBD) with three replications in 2007. Two experiments were conducted in growth chambers, and the environmental conditions were the same in both growth chambers to represent biological replications. In the statistical analysis, the replications were regarded as a random effect, and the wheat cultivars/lines were considered as a fixed effect. Three plants of each cultivar/line were cultivated in individual cones $(3.8 \mathrm{~cm}$ in diameter and $20 \mathrm{~cm}$ long) (Stuewe and Sons), and each cone was 
considered as an experimental unit. In total, nine plants per experiment were rated for each isolate. Plants were considered to be resistant when the lesion types were $<3.0$ and susceptible when the lesion types were $>3.0$ as described above.

Ptr ToxA bioassay. Twenty winter wheat cultivars from Arkansas were evaluated for reactions to Ptr ToxA (Table 2). Purified Ptr ToxA was kindly provided by Steven Meindhart, NDSU, Fargo, ND. Three leaves of each wheat cultivar were infiltrated with Ptr ToxA $(10 \mu \mathrm{g} / \mathrm{ml})$ at the two-leaf stage with a 1-ml needleless syringe (13). The plants were placed in a growth chamber and maintained as mentioned above. Wheat cultivars Glenlea (sensitive to Ptr ToxA) and Salamouni (insensitive to Ptr ToxA) were used as checks. The infiltrated leaves were evaluated for the presence of necrosis (indicating toxin sensitivity) $72 \mathrm{~h}$ after infiltration.

Culture filtrate of AR LonB2 was obtained as described previously (37). Approximately $25 \mu \mathrm{l}$ of the culture filtrate was infiltrated into the second leaf of seedlings using a 1-ml needleless syringe until water-soaking of tissue was observed. The infiltrated leaf was marked with a nontoxic permanent marker, and the plant response to the culture filtrate was recorded 4 days after infiltration. Wheat cultivars Erik (insensitive to Ptr ToxA, Ptr ToxB, and Ptr ToxC), 6B365 (sensitive to Ptr ToxC), 6B662 (sensitive to Ptr ToxB), and Katepwa (sensitive to Ptr ToxA and Ptr ToxB) were included as checks. The plants were rated as sensitive (S) or insensitive (I) based on the presence or absence of necrosis or chlorosis 4 days after infiltration as described previously (27).

\section{RESULTS}

Virulence analysis. Of the 93 isolates tested, 63 induced necrosis and chlorosis on Glenlea and 6B365, respectively, but were avirulent on 6B662 and Salamouni. The 63 isolates were assigned to race 1 (data not shown). Among them, 19 isolates induced necrosis on Glenlea (sensitive to Ptr ToxA), but only six isolates harbored the ToxA gene (Table 1). For example, disease symptoms induced by AR Cross A5 on four wheat cultivars/lines, Glenlea, 6B662, 6B665, and Salamouni, are presented in Figure 2. The 30 remaining isolates resembled race 3 as they exhibited chlorosis on 6B365; however, these isolates were avirulent on Glenlea and 6B662 (data not shown).

Ptr ToxA-based PCR and Southern analyses. Genotypic analysis revealed that 13 of the 19 isolates of $P$. tritici-repentis, which were designated race 1 based on phenotypic analysis, lacked the ToxA gene, suggesting that these isolates may not be race 1 (Table 1). Six isolates (AR ArA5, AR JacB3, AR LonA5, AR PraA1, AR PraA5, and AR PraB1) were found to har- bor the ToxA gene, which is typical of race 1 , and the remaining samples were genomic DNA from "race 1-like isolates" that lack the ToxA gene (Figs. 3 and 4).

Ptr ToxB-based PCR assay. As expected, the majority of the isolates of $P$. tritici-repentis lacked the ToxB gene (Fig. 5). Among the 42 isolates tested, six isolates (AR CrB10, AR CrossB3, AR JacA5, AR JacB3, AR LonA5, and AR LonB5) harbored the ToxB gene. None of the isolate induced chlorosis on 6B662 (sensitive to $\mathrm{Ptr}$ ToxB).
Virulence of isolate AR LonB2 and known races 1,3 , and 5 of $P$. triticirepentis on winter wheat cultivars. The 20 winter wheat cultivars were susceptible to race 1 (Table 2). Nine wheat cultivars were susceptible to race 3 , while all cultivars were resistant to race 5 (Table 2). The results showed that four wheat cultivars (Delta Grow 1600, Delta Grow 4500, Pat, and Pioneer 26 R15) were resistant to race 3 but were susceptible to AR LonB2 (Table 2). Similarly, four wheat cultivars (Agri Pro/Coker 9593, Agri Pro/Coker Magnolia,

Table 1. Phenotypic and genotypic analysis of Pyrenophora tritici-repentis isolates collected from Arkansas

\begin{tabular}{|c|c|c|c|c|}
\hline Isolate $^{a}$ & $\begin{array}{c}\text { Virulence } \\
\text { assay }^{\mathbf{b}}\end{array}$ & $\begin{array}{c}\text { Ptr ToxA- } \\
\text { based PCR } \\
\text { assayc }^{c}\end{array}$ & $\begin{array}{c}\text { Ptr ToxA- } \\
\text { based Southern } \\
\text { analysis }^{\mathrm{d}}\end{array}$ & $\begin{array}{c}\text { Ptr ToxB- } \\
\text { based PCR } \\
\text { assay }^{\mathrm{e}}\end{array}$ \\
\hline AR ArA1 & $\mathrm{Nec}+\mathrm{Chl}+$ & - & - & - \\
\hline AR ArA2 & Nec-Chl+ & - & - & - \\
\hline AR ArA5 & $\mathrm{Nec}+\mathrm{Chl}+$ & + & + & - \\
\hline AR ArB 10 & $\mathrm{Nec}-\mathrm{Chl}+$ & - & - & - \\
\hline AR ArB2 & $\mathrm{Nec}-\mathrm{Chl}+$ & - & - & - \\
\hline AR CrA1 & $\mathrm{Nec}+\mathrm{Chl}+$ & - & - & - \\
\hline AR CrA10 & $\mathrm{Nec}-\mathrm{Chl}+$ & - & - & - \\
\hline AR CrA3 & $\mathrm{Nec}-\mathrm{Chl}+$ & - & - & - \\
\hline AR CrA5 & $\mathrm{Nec}+\mathrm{Chl}+$ & - & - & - \\
\hline AR CrB1 & $\mathrm{Nec}+\mathrm{Chl}+$ & - & - & - \\
\hline AR CrB10 & $\mathrm{Nec}+\mathrm{Chl}+$ & - & - & + \\
\hline AR CrB2 & $\mathrm{Nec}-\mathrm{Chl}+$ & - & - & - \\
\hline AR CrB3 & $\mathrm{Nec}-\mathrm{Chl}+$ & - & - & - \\
\hline AR CrossA1 & Nec-Chl+ & - & - & - \\
\hline AR CrossA10 & $\mathrm{Nec}+\mathrm{Chl}+$ & - & - & - \\
\hline AR CrossB1 & $\mathrm{Nec}+\mathrm{Chl}+$ & - & - & - \\
\hline AR CrossB 10 & $\mathrm{Nec}+\mathrm{Chl}+$ & - & - & - \\
\hline AR CrossB2 & $\mathrm{Nec}-\mathrm{Chl}+$ & - & - & - \\
\hline AR CrossB3 & $\mathrm{Nec}-\mathrm{Chl}+$ & - & - & + \\
\hline AR CrossB5 & $\mathrm{Nec}+\mathrm{Chl}+$ & - & - & - \\
\hline AR JacA1 & $\mathrm{Nec}+\mathrm{Chl}+$ & - & - & - \\
\hline AR JacA5 & $\mathrm{Nec}-\mathrm{Chl}+$ & - & - & + \\
\hline AR JacB10 & $\mathrm{Nec}+\mathrm{Chl}+$ & - & - & - \\
\hline AR JacB3 & $\mathrm{Nec}+\mathrm{Chl}+$ & + & + & + \\
\hline AR JacB4 & $\mathrm{Nec}-\mathrm{Chl}+$ & - & - & - \\
\hline AR LonA1 & $\mathrm{Nec}+\mathrm{Chl}+$ & - & - & - \\
\hline AR LonA10 & $\mathrm{Nec}-\mathrm{Chl}+$ & - & - & - \\
\hline AR LonA3 & $\mathrm{Nec}-\mathrm{Chl}+$ & - & - & - \\
\hline AR LonA5 & $\mathrm{Nec}+\mathrm{Chl}+$ & + & + & + \\
\hline AR LonA8 & Nec-Chl+ & - & - & - \\
\hline AR LonB1 & $\mathrm{Nec}-\mathrm{Chl}+$ & - & - & - \\
\hline AR LonB10 & $\mathrm{Nec}-\mathrm{Chl}+$ & - & - & - \\
\hline AR LonB2 & $\mathrm{Nec}-\mathrm{Chl}+$ & - & - & - \\
\hline AR LonB4 & Nec-Chl+ & - & - & - \\
\hline AR LonB5 & $\mathrm{Nec}-\mathrm{Chl}+$ & - & - & + \\
\hline AR LonB6 & $\mathrm{Nec}-\mathrm{Chl}+$ & - & - & - \\
\hline AR LonB9 & Nec-Chl+ & - & - & - \\
\hline AR PraA1 & $\mathrm{Nec}+\mathrm{Chl}+$ & + & + & - \\
\hline AR PraA3 & $\mathrm{Nec}+\mathrm{Chl}+$ & - & - & - \\
\hline AR PraA5 & $\mathrm{Nec}+\mathrm{Chl}+$ & + & + & - \\
\hline AR PraB1 & $\mathrm{Nec}+\mathrm{Chl}+$ & + & + & - \\
\hline AR PraB5 & $\mathrm{Nec}-\mathrm{Chl+}$ & - & - & - \\
\hline Race 1 (isolate \# Pti2) & $\mathrm{Nec}+\mathrm{Chl}+$ & + & + & - \\
\hline
\end{tabular}

a Isolates originating from Arkansas State (AR) are followed by abbreviations indicating the county of origin. For example, Ar, Cr, Cross, Jac, Lon, and Pra indicate isolates originating from Arkansas, Craighead, Cross, Jackson, Lonoke, and Prairie counties, respectively.

b Variations in the virulence of 42 isolates of $P$. tritici-repentis were based on their ability to induce necrosis and/or chlorosis on five differential wheat cultivars/lines-Glenlea, 6B365, 6B662, Salamouni, and Katepwa-8 days postinoculation (26,27,29). Abbreviations: Nec+ and Nec- represent the presence and absence of necrosis on wheat cultivar Glenlea, respectively; Chl+ refers to the presence chlorosis on wheat line 6B365.

c $P$. tritici-repentis isolates were analyzed by polymerase chain reaction (PCR) for the presence of the ToxA gene as described previously (19).

d To reconfirm the presence of the ToxA gene in Arkansas isolates, Southern analysis was performed as described previously (16).

e Isolates were analyzed for the presence of the ToxB gene as described previously (7). 
Pioneer 26 R87, and Progeny 166) were susceptible to race 3 , but these cultivars were resistant to AR LonB2, indicating that this isolate could be different from race 3 .

Ptr ToxA bioassay. Glenlea and Salamouni exhibited sensitive (necrosis) and insensitive (no necrosis) reactions to Ptr ToxA, respectively. None of the 20 winter wheat cultivars from Arkansas exhibited necrosis when infiltrated with Ptr ToxA, indicating that these wheat cultivars do not possess the Tsn1 gene (Table 2).

\section{DISCUSSION}

Considerable success has been achieved in understanding wheat $-P$. tritici-repentis interactions in the last two decades. A complex structure consisting of eight races of P. tritici-repentis has been reported on the basis of differential responses on the wheat cultivars/lines $(31,42)$. Molecular analysis revealed that the three HSTs produced by $P$. tritici-repentis are virulence determinants that can distinguish the fungus in terms of races $(11,13,27,37)$. In this study, 93 isolates of $P$. tritici-repentis collected from Arkansas were analyzed for their virulence on five wheat cultivars/lines and for the presence or absence of the ToxA and ToxB genes based on PCR and Southern blot analyses. The results showed that the six isolates produced necrotic (similar to race 1) and chlorotic (similar to races 1 and 3) symptoms on Glenlea and 6B365, respectively, but were avirulent on 6B662 and Salamouni. It appeared that these six isolates can be categorized as race 1 according to the current race classification scheme $(26,27,42)$. Another group contained 13 isolates that induce necrosis on Glenlea but did not harbor the ToxA gene. Therefore, these isolates did not fit in the current race classification, suggesting that these isolates may contain different toxin compounds that can induce a similar disease phenotype ( $\mathrm{Ptr}$

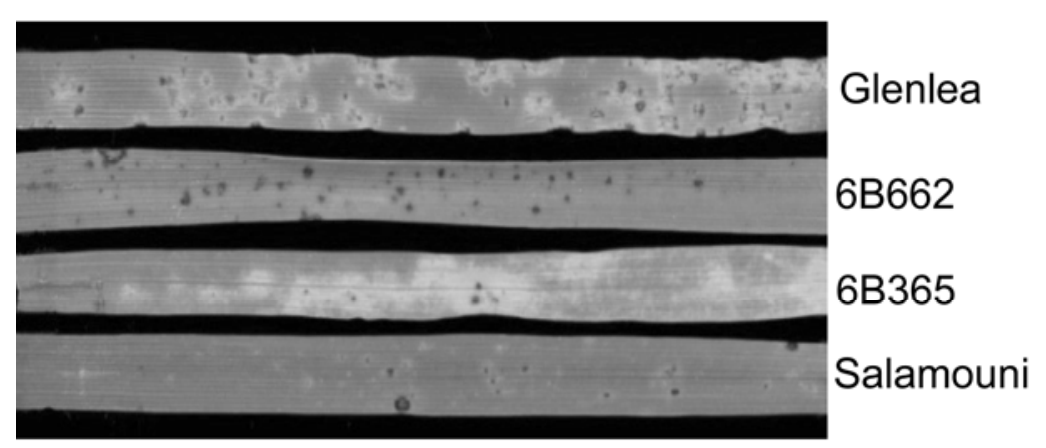

Fig. 2. Reactions of isolate AR Cross A5 (unclassified race) of Pyrenophora tritici-repentis from Arkansas on wheat cultivars/lines. AR CrossA5 induced necrosis on Glenlea and chlorosis on 6B365, respectively, but was avirulent (no disease symptoms) on 6B662 and Salamouni.

Table 2. Reactions of 20 winter wheat cultivars from Arkansas to isolate AR LonB2 (unclassified race) and three known races, 1,3, and 5, of Pyrenophora tritici-repentis

\begin{tabular}{|c|c|c|c|c|c|c|}
\hline Winter wheat cultivars ${ }^{a}$ & $\begin{array}{c}\text { Race } 1 \\
\text { (isolate \# Pti2) }\end{array}$ & $\begin{array}{c}\text { Race } 3 \text { (isolate } \\
\text { \# Ptr 331-9) }\end{array}$ & $\begin{array}{c}\text { Race } 5 \\
\text { (isolate \# DW7) }\end{array}$ & $\underset{(C F)^{b}}{A R \text { LonB2 }}$ & AR LonB2 & $\begin{array}{c}\text { Purified } \\
\text { Ptr ToxA }^{\mathbf{c}}\end{array}$ \\
\hline Agri Pro/Coker 9593 & $4.6(\mathrm{~S})$ & $3.9(\mathrm{~S})$ & $1.0(\mathrm{R})$ & I & $1.2(\mathrm{R})$ & I \\
\hline Agri Pro/Coker Beretta & $4.0(\mathrm{~S})$ & $1.6(\mathrm{R})$ & $1.3(\mathrm{R})$ & I & $1.5(\mathrm{R})$ & I \\
\hline Agri Pro/Coker Magnolia & $4.6(\mathrm{~S})$ & $3.5(\mathrm{~S})$ & $1.1(\mathrm{R})$ & I & $2.2(\mathrm{R})$ & I \\
\hline AGS 2000 & $4.3(\mathrm{~S})$ & $1.6(\mathrm{R})$ & $1.1(\mathrm{R})$ & I & $1.4(\mathrm{R})$ & I \\
\hline AGS 2050 & $4.3(\mathrm{~S})$ & $3.5(\mathrm{~S})$ & $2.5(\mathrm{R})$ & I & $3.9(\mathrm{~S})$ & I \\
\hline Armor 5110 & $4.2(\mathrm{~S})$ & $3.1(\mathrm{~S})$ & $1.0(\mathrm{R})$ & I & $4.2(\mathrm{~S})$ & I \\
\hline Croplan Genetics 554W & $4.1(\mathrm{~S})$ & $1.8(\mathrm{R})$ & $1.1(\mathrm{R})$ & I & $1.9(\mathrm{R})$ & I \\
\hline Croplan Genetics 8302 & $4.1(\mathrm{~S})$ & $1.3(\mathrm{R})$ & $1.2(\mathrm{R})$ & I & $2.9(\mathrm{R})$ & I \\
\hline Delta Grow 1600 & $4.2(\mathrm{~S})$ & $1.3(\mathrm{R})$ & $1.1(\mathrm{R})$ & I & $3.3(\mathrm{~S})$ & I \\
\hline Delta Grow 4500 & $4.6(\mathrm{~S})$ & $1.7(\mathrm{R})$ & $1.0(\mathrm{R})$ & I & $4.1(\mathrm{~S})$ & I \\
\hline Delta King 7710 & $4.3(\mathrm{~S})$ & $3.9(\mathrm{~S})$ & $1.7(\mathrm{R})$ & I & $4.3(\mathrm{~S})$ & I \\
\hline Dixie $989^{\circ}$ & $4.8(\mathrm{~S})$ & $3.4(\mathrm{~S})$ & $1.1(\mathrm{R})$ & I & $3.6(\mathrm{~S})$ & I \\
\hline Hornbeck 3266 & $4.9(\mathrm{~S})$ & $4.2(\mathrm{~S})$ & $2.1(\mathrm{R})$ & I & $4.2(\mathrm{~S})$ & I \\
\hline Pat & $3.9(\mathrm{~S})$ & $1.0(\mathrm{R})$ & $1.0(\mathrm{R})$ & I & $4.1(\mathrm{~S})$ & I \\
\hline Pioneer 26 R15 & $4.8(\mathrm{~S})$ & $1.6(\mathrm{R})$ & $1.1(\mathrm{R})$ & I & $3.4(\mathrm{~S})$ & I \\
\hline Pioneer 26 R22 & $4.8(\mathrm{~S})$ & $1.6(\mathrm{R})$ & $1.2(\mathrm{R})$ & I & $2.2(\mathrm{R})$ & I \\
\hline Pioneer 26 R87 & $4.9(\mathrm{~S})$ & $3.7(\mathrm{~S})$ & $1.5(\mathrm{R})$ & I & $1.2(\mathrm{R})$ & I \\
\hline Progeny 166 & $4.8(\mathrm{~S})$ & $3.6(\mathrm{~S})$ & $1.1(\mathrm{R})$ & I & $2.0(\mathrm{~S})$ & I \\
\hline Terral 8558 & $4.7(\mathrm{~S})$ & $1.8(\mathrm{R})$ & $1.0(\mathrm{R})$ & I & $1.5(\mathrm{R})$ & I \\
\hline Terral LA 481 & $4.7(\mathrm{~S})$ & $1.2(\mathrm{R})$ & $1.0(\mathrm{R})$ & I & $1.9(\mathrm{R})$ & I \\
\hline $6 \mathrm{~B} 365$ & $5.0(\mathrm{~S})$ & $4.9(\mathrm{~S})$ & $1.1(\mathrm{R})$ & I & $4.8(\mathrm{~S})$ & I \\
\hline Erik (resistant check) & $1.0(\mathrm{R})$ & $1.0(\mathrm{R})$ & $1.0(\mathrm{R})$ & I & $1.1(\mathrm{R})$ & I \\
\hline Katepwa & $4.5(\mathrm{~S})$ & N/A & $4.5(\mathrm{~S})$ & I & $3.9(\mathrm{~S})$ & $\mathrm{S}$ \\
\hline $6 \mathrm{~B} 662$ & N/A & $1.5(\mathrm{R})$ & $4.5(\mathrm{~S})$ & I & $2.0(\mathrm{R})$ & I \\
\hline
\end{tabular}

a Plants were rated on a 1 to 5 lesion-type scale (26). Plants with ratings $<3.0$ were classified as resistant (R), and those with ratings $>3.0$ were classified as susceptible (S). Wheat cultivars/lines Erik, 6B662, and 6B365 were used for race confirmation and inoculation validation. Erik was used as a resistant check, and Katepwa and 6B365 were used as susceptible checks for race 1 confirmation and inoculation validation; Erik and 6B365 were used for race 3 verifications and inoculation validation; $6 \mathrm{~B} 662$ was used for race 5 verification and inoculation validation. $\mathrm{S}=$ susceptible, $\mathrm{R}=$ resistant, and $\mathrm{N} / \mathrm{A}=$ not available.

${ }^{\mathrm{b}}$ Culture filtrate (CF) $(25 \mu \mathrm{l})$ from isolate AR LonB2 was introduced into the second leaf of wheat seedlings until water-soaking was observed. Four days after infiltration, plants were rated as sensitive (S) or insensitive (I) based on presence and absence of necrosis or chlorosis at the infiltration site, respectively.

${ }^{c}$ Three leaves of each wheat cultivar were infiltrated with purified Ptr ToxA $(10 \mu \mathrm{g} / \mathrm{ml})$ using a 1-ml needleless syringe at the two-leaf stage as described previously (13). Infiltrated plants were placed in a growth chamber. The leaves were assessed for their reaction based on the presence (toxin sensitive $=\mathrm{S}$ ) or absence (toxin insensitive $=\mathrm{I}$ ) of necrosis $72 \mathrm{~h}$ after infiltration. 
$(21,42)$, which also predicted the production of additional toxins based on the reactions of certain wheat genotypes. Further studies are necessary to investigate the presence of additional toxin in $P$. triticirepentis race 3 from Arkansas.

A detailed molecular analysis for detecting HSTs is necessary to better understand race structure and dynamics of variation in P. tritici-repentis populations. Although Ptr ToxB is associated with chlorosis on 6B662 and Katepwa, and Ptr ToxC is asso-
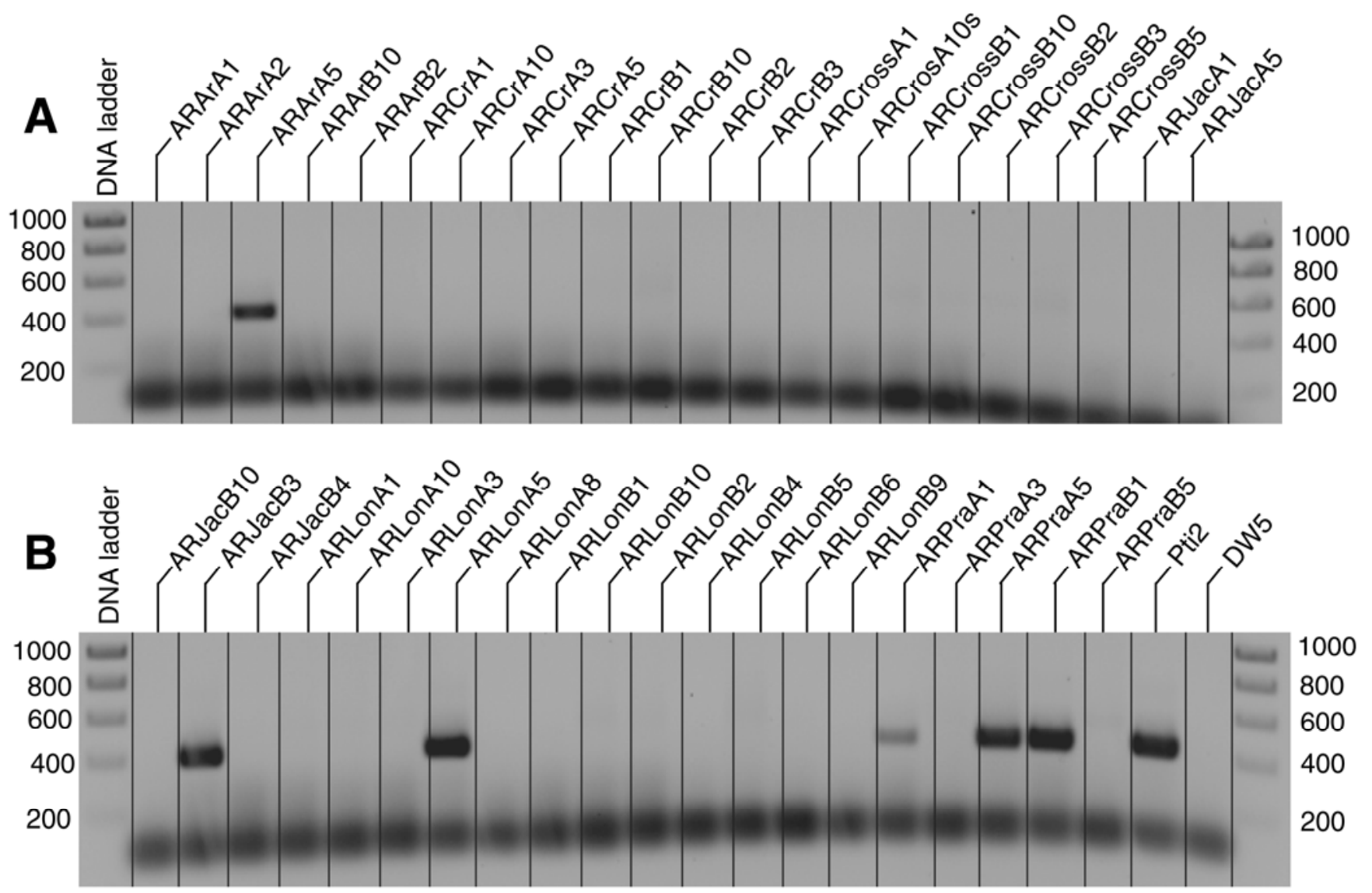

Fig. 3. Agarose gels showing the presence or absence of the ToxA gene in 42 isolates of Pyrenophora tritici-repentis from Arkansas detected by Ptr ToxAbased polymerase chain reaction (PCR) analysis. Lane 1: 200-bp DNA ladder.

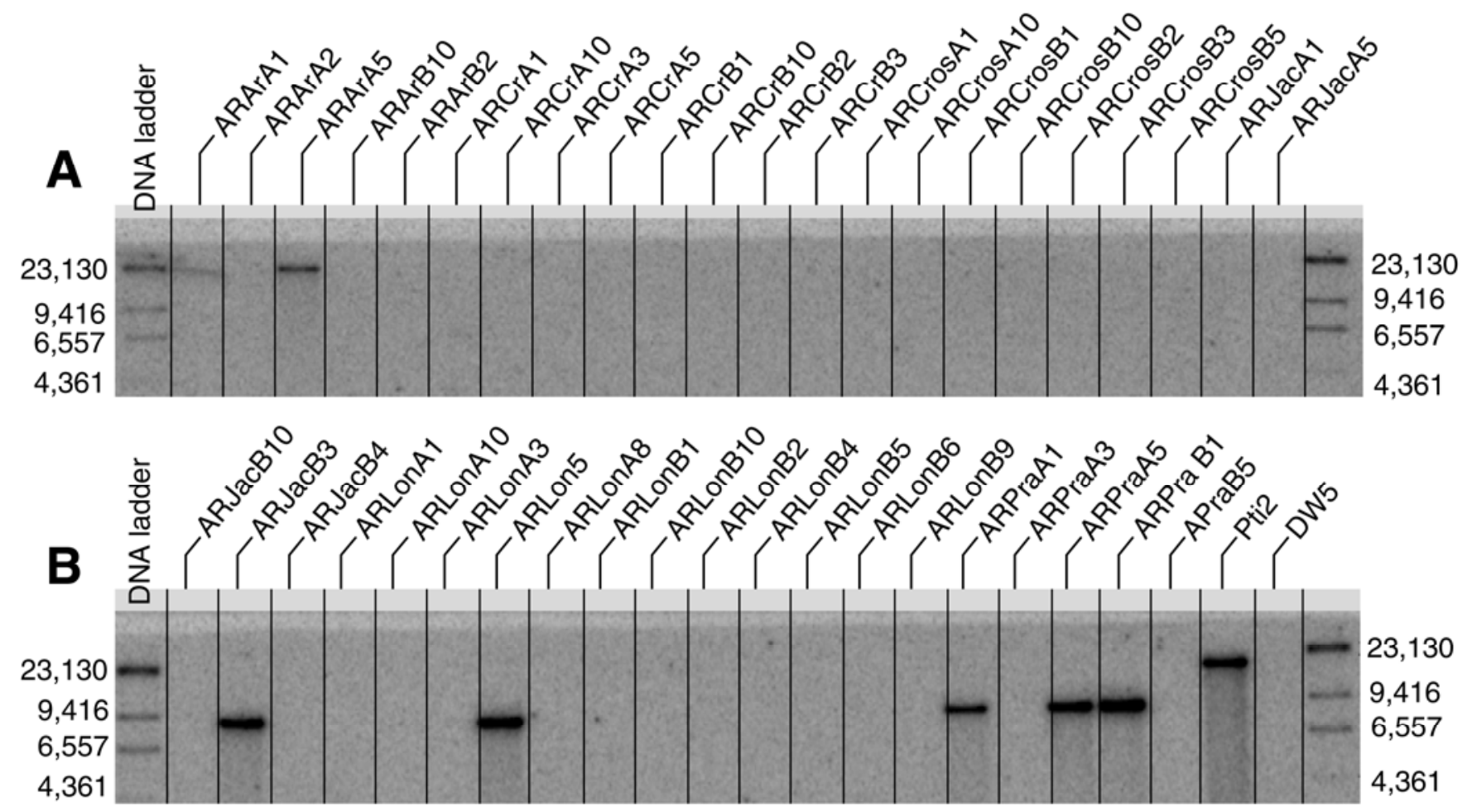

Fig. 4. Detection of the ToxA gene in 42 isolates of Pyrenophora tritici-repentis from Arkansas by ToxA-based Southern analysis. Lane 1: Lambda DNA. 
ciated with chlorosis on 6B365, both Ptr ToxA and Ptr ToxB have predominantly been found in separate isolates $(30,31,44)$. We used a ToxA-based PCR assay to determine if the ToxA gene was present in $P$. tritici-repentis isolates. The Ptr ToxAbased PCR analysis confirmed by Southern analysis suggested that these isolates designated as race 1 based on the virulence phenotypes did not correspond to race 1 using a molecular genotyping. The 36 isolates out of 42 characterized in this study lacked the ToxA gene. Our results suggest that these isolates possess a novel toxin(s) that enables them to induce necrotic symptoms similar to those of $\mathrm{Ptr}$ ToxA.

Three chlorosis-inducing (nec-chl+) isolates (AR CrossB3, AR JacA5, and AR LonB5) resembling race 3 harbor the ToxB gene (Table 1). Another three necrosis- and chlorosis-inducing (nec+chl+) isolates ( $\mathrm{AR}$ CrB10, AR JacB3, and AR LonA5) also carry the ToxB gene. However, the majority (36 out of 42 isolates) were capable of inducing chlorosis on wheat line 6B365 but lacked the ToxB gene. The $P$. triticirepentis races $5,6,7$, and 8 harbor the Tox $B$ gene, which is known to produce $\mathrm{Ptr}$ ToxB $(31,42)$. Recent findings show that ToxB-like sequences have been found in races 3 and 4 of the fungus, which do not possess Ptr ToxB activity (41), as well as in other members of ascomycetes that do not infect wheat (8). Additionally, the form of Ptr ToxB from avirulent race 4 isolates, which lack chlorosis-inducing activity, has been found in Canada (25). We did not perform sequence analysis of the isolates tested in this study. Thus, it is uncertain whether the chlorosis-inducing activity was due to the form of the ToxB-like sequences present or reaction of the host to infection.

Race 3 isolates of $P$ tritici-repentis have been reported from different continents $(1,17,42)$. The development of race 3 specific primers would facilitate the identification of chlorosis-inducing isolates of $P$ tritici-repentis (7). One of the limitations of the present study is lack of a screening procedure for the ToxC gene in $P$. triticirepentis race 3 isolates from Arkansas. Although Ptr ToxC can induce chlorosis in wheat line 6B365, this toxin is highly unstable (S. W. Meinhardt, personal communication).

In Arkansas, cultivation of wheat began in the early 1960s, and approximately 1.014 million acres were planted with winter wheat from 1993 to 2003 (9). However, tan spot disease was only first re- ported on wheat in Arkansas in 1989 (22). The 20 winter wheat cultivars from Arkansas were susceptible to race 1 , but these were insensitive to Ptr ToxA. It appears that $T s n 1$ is not present in most wheat cultivars grown in Arkansas. Although the mechanisms of the evolution of a new race(s) in the fungal population from Arkansas are unknown, an effort to identify a new pathogenic race(s) and to characterize a novel toxin(s) in P. tritici-repentis isolates is in progress. This will advance our knowledge on the intricacies of this pathosystem.

In conclusion, the Arkansas isolates infect wheat cultivars differentially, and may provide an excellent opportunity to explore the relationship between $P$. tritici-repentis and wheat reported previously in this biological system as well as in Stagonospora nodorum $(19,20)$, which follows an inverse gene-for-gene model. Comparison of virulence of races 1,3 , and 5 of $P$. triticirepentis with the Arkansas isolate on wheat cultivars showed that an additional virulence factor(s) other than Ptr ToxA and Ptr ToxC is present in AR LonB2. Thus, wheat cultivars such as Delta Grow 1600, Delta Grow 4500, and Pat (Table 2) may serve as good candidates and will be of great benefit for characterizing virulence
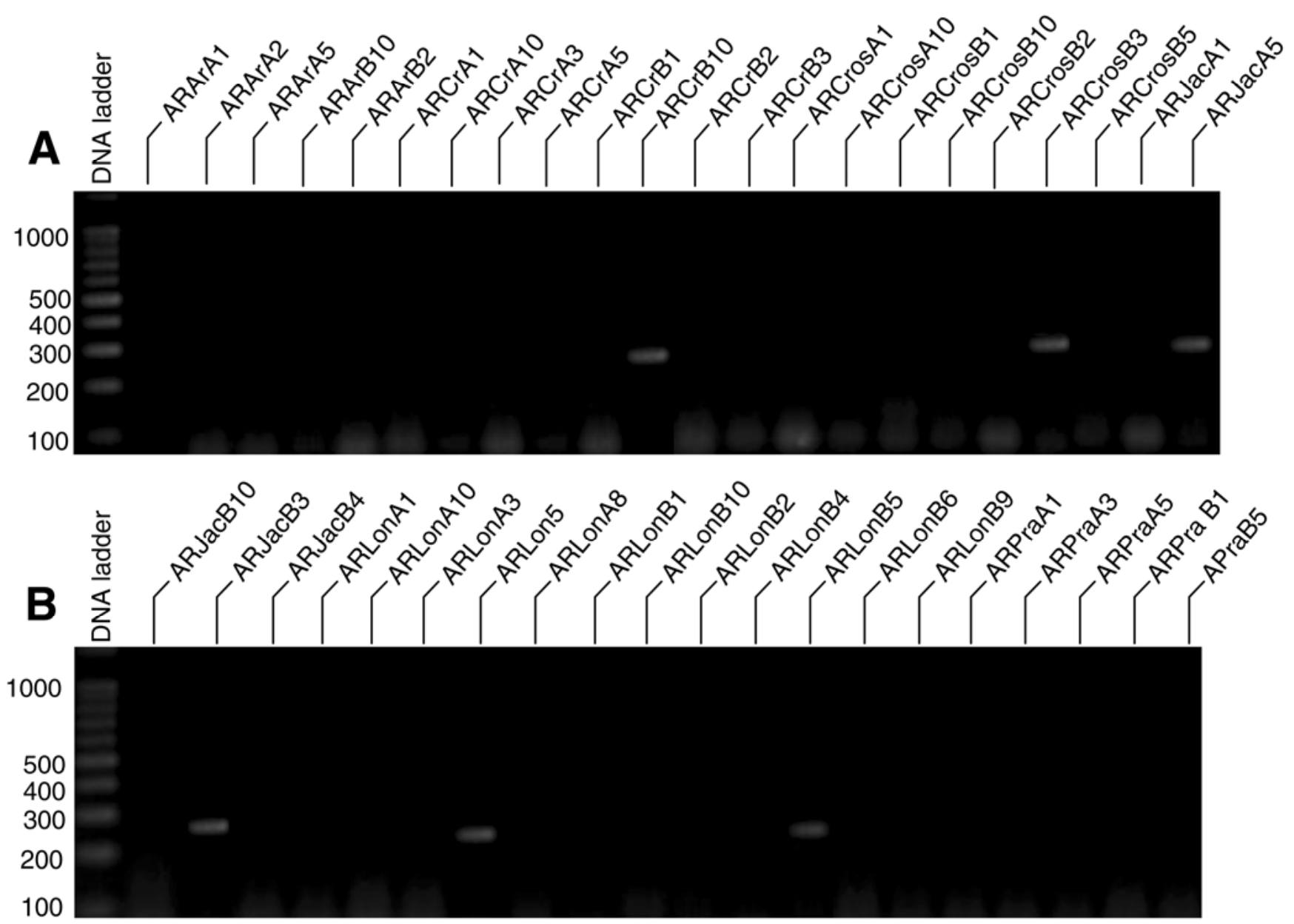

Fig. 5. Agarose gels showing the presence or absence of the ToxB gene in 42 isolates of Pyrenophora tritici-repentis from Arkansas generated by Ptr ToxBbased polymerase chain reaction (PCR) analysis. Lane 1: 100-bp DNA ladder. 
factors in the Arkansas isolates. Additionally, these novel isolates will be useful for testing resistance to $P$. tritici-repentis in wheat breeding programs.

\section{ACKNOWLEDGMENTS}

Financial support from State Board of Agricultural Research and Education, ND, and the North Dakota State University Agricultural Experiment Station is greatly acknowledged. We thank G. Milus and R. Cartwright for collecting leaf material from Arkansas, Tim Friesen and Danielle Holmes for providing excellent technical assistance in ToxA-based PCR and Southern analyses, and Mary Pull for editing the manuscript.

\section{LITERATURE CITED}

1. Adhikari, T. B., Ali, S., Myrfield, M., and Burlakoti, R. R. 2008. The global genetic structure of Pyrenophora tritici-repentis populations. (Abstr.) Phytopathology 98:S10.

2. Adhikari, T. B., Bai, J., Meinhardt, S. W., Gurung, S., Myrfield, M., Patel, J., Ali, S., Gudmestad, N. C., and Rasmussen, J. B. 2009. Tsn 1-mediated host responses to ToxA from Pyrenophora tritici-repentis. Mol. PlantMicrobe Interact. 22:1056-1068.

3. Ali, S., Cartwright, R., Friesen, T., Rasmussen, J., and Milus, G. 2003. Novel Pyrenophora tritici-repentis isolate from Arkansas wheat. (Abstr.) Phytopathology 93:S3.

4. Ali, S., and Francl, L. J. 1999. Races of Pyrenophora tritici-repentis on durum in the northern Great Plains of the U.S. (Abstr.) Phytopathology 89:S2.

5. Ali, S., and Francl, L. J. 2003. Population race structure of Pyrenophora tritici-repentis prevalent on wheat and noncereal grasses in the Great Plains. Plant Dis. 87:418-422.

6. Anderson, J. A., Effertz, R. J., Faris, J. D., Francl, L. J., Meinhardt, S. W., and Gill, B. S. 1999. Genetic analysis of sensitivity to a Pyrenophora tritici-repentis necrosis-inducing toxin in durum and common wheat. Phytopathology 89:293-297.

7. Andrie, R. M., Pandelova, I., and Ciuffetti, L. M. 2007. A combination of phenotypic and genotypic characterization strengthens Pyrenophora tritici-repentis race identification. Phytopathology 97:694-701.

8. Andrie, R. M., Schoch, C. L., Hedges, R., Spatafora, J. W., and Ciuffetti, L. M. 2008. Homologos of ToxB, a host-selective toxin gene from Pyrenophora tritici-repentis, are present in the genome of sister-species Pyrenophora bromi and other members of the Ascomycota. Fungal Genet. Biol. 45:363-377.

9. Bacon, R. K., Kolb, F. L., and Murphy, J. P. 2001. The U.S. Soft Red Wheat Pool. Pages 469-478 in: The World Wheat Book. A. Bonjean and W. Angus, eds. Editions Lavoisier, Cachan, France.

10. Ballance, G. M., Lamari, L., Kowatsch, R., and Bernier, C. C. 1996. Cloning, expression and occurrence of the gene encoding the Ptr necrosis toxin from Pyrenophora tritici-repentis. Mol. Plant Pathol. http://www.bspp.org.uk/ mppol/1996/1209ballance/. Published online.

11. Ciuffetti, L. M., Tuori, R. P., and Gaventa, J. M. 1997. A single gene encodes a selective toxin causal to the development of tan spot of wheat. Plant Cell 9:135-144.

12. De Wolf, E. D., Effertz, R. J., Ali, S., and Francl, L. J. 1998. Vistas of tan spot research. Can. J. Plant Pathol. 20:349-370.

13. Effertz, R. J., Meinhardt, S. W., Anderson, J. A., Jordahl, J. G., and Francl, L. J. 2002. Identification of a chlorosis-inducing toxin from Pyrenophora tritici-repentis and the chromo- somal location of an insensitivity locus in wheat. Phytopathology 92:527-533.

14. Engle, J. S., Madden, L. V., and Lipps, P. E. 2006. Distribution and pathogenic characterization of Pyrenophora tritici-repentis and Stagonospora nodorum in Ohio. Phytopathology $96: 1355-1362$

15. Faris, J. D., Anderson, J. A., Francl, L. J., and Jordahl, J. G. 1996. Chromosomal location of a gene conditioning insensitivity in wheat to a necrosis-inducing culture filtrate from Pyrenophora tritici-repentis. Phytopathology 86:459463.

16. Faris, J. D., Haen, K. M., and Gill, B. S. 2000. Saturation mapping of a gene-rich recombination hot spot region in wheat. Genetics 154:823-835.

17. Friesen, T. L., Ali, S., Klein, K. K., and Rasmussen, J. B. 2005. Population genetic analysis of a global collection of Pyrenophora tritici-repentis, causal agent of tan spot of wheat. Phytopathology 95:1144-1150.

18. Friesen, T. L., and Faris, J. D. 2004. Molecular mapping of resistance to Pyrenophora triticirepentis race 5 and sensitivity to $P \operatorname{tr} \operatorname{ToxB}$ in wheat. Theor. Appl. Genet. 109:464-471

19. Friesen, T. L., Stukenbrock, E. H., Liu, Z. H., Meinhardt, S., Ling, H., Faris, J. D., Rasmussen, J. B., Solomon, P. S., McDonald, B. A., and Oliver, R. P. 2006. Emergence of a new disease as a result of interspecific virulence gene transfer. Nat. Genet. 38:953-956.

20. Friesen, T. L., Zhang, Z., Solomon, P. S., Oliver, R. P., and Faris, J. D. 2008. Genetic characterization of a novel wheatStagonospora nodorum host-selective toxin interaction and it role in disease susceptibility. Plant Physiol. 146:682-693.

21. Gamba, F. M., Lamari, L., and Brule-Babel, A. L. 1998. Inheritance of race-specific necrotic and chlorotic reactions induced by Pyrenophora tritici-repentis in hexaploid wheats. Can. J. Plant Pathol. 20:401-407.

22. Hirrell, M. C., Spradley, J. P., Mitchell, J. K., and Wilson, E. W. 1990. First report of tan spot caused by Drechslera tritici-repentis on winter wheat in Arkansas. Plant Dis. 74:252.

23. Hosford, R. M., Jr. 1982. Tan spot. Pages 1-24 in: Tan Spot of Wheat and Related Disease Workshop. R. M. Hosford Jr., ed. North Dakota Agric. Exp. Stn., Fargo.

24. Jordahl, J. G., and Francl, L. J. 1992. Increase and storage of cultures of Pyrenophora triticirepentis. Page 109 in: Advances in Tan Spot Research. L. J. Francl, J. M. Krupinsky, and M. P. McMullen, eds. North Dakota Agric. Exp. Stn., Fargo.

25. Kim, Y. M., and Strelkov, S. E. 2007. Heterologous expression and activity of Ptr ToxB from virulent and avirulent isolates of Pyrenophora tritici-repentis. Can. J. Plant Pathol. 29:232-242.

26. Lamari, L., and Bernier, C. C. 1989. Evaluation of wheat lines and cultivars to tan spot [Pyrenophora tritici-repentis] based on lesion type. Can. J. Plant Pathol. 11:49-56.

27. Lamari, L., and Bernier, C. C. 1989. Toxin of Pyrenophora tritici-repentis: Host-specificity, significance in disease, and inheritance of host reaction. Phytopathology 79:740-744.

28. Lamari, L., Gilbert, J., and Tekauz, A. 1998. Race differentiation in Pyrenophora triticirepentis and survey of physiologic variation in western Canada. Can. J. Plant Pathol. 20:396400.

29. Lamari, L., McCallum, B. D., and dePauw, R. M. 2005. Forensic pathology of Canadian bread wheat: The case of tan spot. Phytopathology 95:144-152.

30. Lamari, L., Sayoud, R., Boulif, M., and
Bernier, C. C. 1995. Identification of a new race in Pyrenophora tritici-repentis: Implications for the current pathotype classification system. Can. J. Plant Pathol. 17:312-318.

31. Lamari, L., Strelkov, S. E., Yahyaoui, A., Orabi, J., and Smith, R. B. 2003. The identification of two new races of Pyrenophora triticirepentis from the host center of diversity confirms a one-to-one relationship in tan spot of wheat. Phytopathology 93:391-396.

32. Manning, V. A., Andrie, R. M., Trippe, A. F., and Ciuffetti, L. M. 2004. Ptr ToxA requires multiple motifs for complete activity. Mol. Plant-Microbe Interact. 17:491-501.

33. Manning, V. A., Chu, A., Steeves, J. E., Wolpert, T. J., and Ciuffetti, L. M. 2009. A hostselective toxin of Pyrenophora tritici-repentis, Ptr ToxA, induces photosystem changes and reactive oxygen species accumulation in sensitive wheat. Mol. Plant-Microbe Interact. 22:665-676.

34. Manning, V. A., and Ciuffetti, L. M. 2005 Localization of Ptr ToxA produced by Pyrenophora tritici-repentis reveals protein import into wheat mesophyll cells. Plant Cell 17:3203-3212.

35. Manning, V. A., and Ciuffetti, L. M. 2007. Ptr ToxA interacts with a chloroplast-localized protein. Mol. Plant-Microbe Interact. 20:168177.

36. Manning, V. A., Hamilton, S. M., Karplus, P. A., and Ciuffetti, L. M. 2008. The Arg-GlyAsp-containing, solvent-exposed loop of Ptr ToxA is required for internalization. Mol. Plant-Microbe Interact. 21:315-325.

37. Orolaza, N. P., Lamari, L., and Ballance, G. M. 1995. Evidence of a host-specific chlorosis toxin from Pyrenophora tritici-repentis, the causal agent of tan spot of wheat. Phytopathology 85:1282-1287.

38. Rees, R. G., Platz, G. J., and Mayer, R. J. 1988. Susceptibility of Australian wheats to Pyrenophora tritici-repentis. Aust. J. Agric. Res. 39:141-151.

39. Sarma, G. N., Manning, V. M., Ciuffetti, L. M., and Karplus, P. A. 2005. Structure of Ptr ToxA An RGD-containing host-selective toxin from Pyrenophora tritici-repentis. Plant Cell 17:3190-3202.

40. Shabeer, A., and Bockus, W. W. 1988. Tan spot effects on yield and yield components relative to growth stage in winter wheat. Plant Dis. 72:599-602.

41. Strelkov, S. E., Kowatsch, R. F., Ballance, G. M., and Lamari, L. 2006. Characterization of the ToxB gene from North African and Canadian isolates of Pyrenophora tritici-repentis. Physiol. Mol. Plant Pathol. 67:164-170.

42. Strelkov, S. E. and Lamari, L. 2003. Hostparasite interaction in tan spot Pyrenophora tritici-repentis of wheat. Can. J. Plant Pathol. 25:339-349.

43. Strelkov, S. E., Lamari, L., and Ballance, G. M. 1998. Induced chlorophyll degradation by a chlorosis toxin from Pyrenophora triticirepentis. Can. J. Plant Pathol. 20:428-435.

44. Strelkov, S. E., Lamari, L., Sayoud, R., and Smith, R. B. 2002. Comparative virulence of chlorosis-inducing races of Pyrenophora tritici-repentis. Can. J. Plant Pathol. 24:2935 .

45. Wolpert, T. J., Dunkle, L. D., and Ciuffetti, L. M. 2002. Host-selective toxins and avirulence determinants: What's in a name? Annu. Rev. Phytopathol. 40:251-285.

46. Zhang, H., Francl, L. J., Jordahl, J. G., and Meinhardt, S. W. 1997. Structural and physical properties of a necrosis-inducing toxin from Pyrenophora tritici-repentis. Phytopathology 87:154-160. 